\title{
Doomed by Dumsor? :
}

\section{Impacts and Implications of Ghana's Load Shedding Crisis}

\author{
Chelsea Ruiter \\ Carleton University
}

\begin{abstract}
Many developing countries struggle with providing basic infrastructure to their citizens; however, the current electricity crisis in Ghana is particularly unique in terms of both duration and intensity. The economic impacts of these load shedding practices are currently estimated to be more than $\$ 2$ million USD daily, with incalculable costs incurred to social development. There is a lack of political will among Ghanaian politicians to critically address the issue outside of short-term measures prior to elections to placate the voting public. The goal of this policy brief is to suggest a number of practical, actionable policy options that the Ghanaian government could implement to mitigate their energy crisis in both the shortand long-term.
\end{abstract}

\section{Introduction}

Walking down the streets of Accra in the middle of the afternoon, it is not uncommon to observe seamstresses sitting beside silent sewing machines, mechanics talking on cell phones outside their garages, and shopkeepers waiting inside darkened storefronts. All these people have the skills, knowledge, equipment, and ambition necessary to successfully run their businesses; however, they are missing one crucial element: electricity. Dumsor, a word used for power blackouts because it means "offon" in Twi (Quartey 2016), has become a part of everyday vernacular in Ghana as the country has been struggling with ongoing and worsening power outages since 2012 (Wadie 2015). In Accra, it is now typical for residents to be without power for at least 12 hours a day. Diesel-powered generators which could maintain a consistent electrical supply are out of reach financially for all but the wealthiest citizens, with only $20 \%$ of small and medium enterprise owners having access to a generator (Ackah 2015).

\section{Background}

Electrification is an element of infrastructure that is critical in a developing country as it has wide-ranging impacts across many development indicators (Anuomi 2015). Yet many countries in the developing world, including Ghana, have struggled to meet the electrical demands of their citizens. The emerging middle class, and their desire for electronic goods such as air conditioners, televisions, and refrigerators, has resulted in demand for electricity growing more rapidly than the aging and worn-down electrical grid can accommodate (Heeralall and Abdelkrim 2012). Load shedding, also known as rolling blackouts, is a practice used by electrical companies to reduce the load on the electrical grid when demand exceeds the amount of power generated (Eskom South Africa n.d.). Although meant to be an emergency measure to stop a country-wide blackout from occurring, in Ghana it has become the daily routine rather than a rare occurrence.

Currently, a majority of Ghana's electricity is sourced from three major dams along the Volta River (USAID n.d.), and this reliance on hydroelectricity makes the power supply vulnerable to the effects of climate change. Ghana is increasingly experiencing changing and unpredictable rainfall patterns characterized by both prolonged dry spells and flooding (Rademacher-Schulz and Salifu Mahama 2012). As a result, the 
water levels at the dams have consistently been far lower than anticipated, and the dams are generating below their stated capacity resulting in a 500 megawatt deficit (Wadie 2015). While some government officials remain convinced that the hydroelectric system can recover (Ghanaian Chronicle 2015), it is clear that the ongoing future impacts of climate change make this an unreliable long term source of power in Ghana.

\section{Developmental Impacts}

The developmental impacts of dumsor are clear and concerning. Economically, the country has suffered significantly from the crisis, and there is an observable correlation between the onset of severe load shedding in 2012 and Ghana's fall from being the world's fastest growing economy in 2011 with a GDP growth rate of $14 \%$ to just $4 \%$ in 2014 (World Bank Databank 2015) (Heeralall and Abdelkrim 2012). In fact, USAID categorized "the unreliable and inadequate supply of electric power . . . [as] one of Ghana's paramount constraints to economic growth" (USAID n.d.). The University of Ghana's Institute of Statistical, Social and Economic Research released a report estimating the economic losses of dumsor to be roughly $\$ 2.2$ million USD every day (Ackah 2015), and inflation has risen 53\% from 2010 levels. (World Bank Databank 2015) However, the impacts of Ghana's dumsor crisis are not limited to the economic sphere. Ongoing load shedding is also having a profoundly negative impact on other social development indicators. Health centres find it impossible to reliably perform life-saving treatments such as kidney dialysis (Antwi 2015), students lack the light necessary to study for important exams, and teachers experience difficulties when trying to make use of any technology in the classroom (NewsGhana February 2015).

Despite the severity of the long-term impacts of load shedding, politicians in Ghana are focused on shortterm solutions for political gain. A presidential election is coming up in November 2016, and the current government faces increasing criticism for its failure to correct the dumsor crisis. In an attempt to placate the public, the government has rented two power barges from Turkey which have docked off the coast of Ghana and are generating additional power to supplement the grid's supply (NewsGhana December 2015). The electrical tariff for both residential and commercial customers has also increased more than $100 \%$ in an attempt to generate funds to finance the government's remedy (Electricity Company of Ghana 2014). However, these short-term actions are aimed to temporarily fix the problem in the pre-writ period rather than establish effective, sustainable solutions.

\section{Policy Recommendations}

There are a number of short- and long-term policies that the Ghanaian government should implement to move towards the goal of sufficient electrical supply.

Short-term policy options

Obviously there is no quick solution to such a serious and complicated problem; however, there are some immediate policy options that could mitigate the harmful effects of dumsor.

1. The electrical company should actually adhere to the published dumsor schedule to allow citizens to prepare for blackout periods. Currently about two-thirds of all power outages are unscheduled, and this uncertainty contributes to Ghanaians' frustrations with the situation (Aiddoo 2016).

2. Having shorter rolling blackouts that cycle more quickly, perhaps on an hourly or bi-hourly basis rather than sustained 12 to 24 hour blackout periods, would also be less disruptive to daily activities as one area would never be without power for too long. 
3. Serious consideration should be given towards establishing a mobile payment system as Ghana has a very high rate of mobile coverage (World Bank Databank 2015), and these kinds of payment systems have proved successful in other sub-Saharan African countries such as Kenya (Dunn 2015). One of the government's major defences of their inaction on the load shedding crisis is that the electrical tariff collection system is ineffective which leads to not enough money available to invest in improvements and repairs to the grid (Ghanaian Chronicle 2015). Implementation of a mobile-payment system could address known barriers to tariff collection by eliminating the need for individuals to queue to pay their monthly bills at banks or utility centres (World Bank Group n.d.).

\section{Long-term policy options}

In the long term, it is crucial that the government moves away from a concentration on unreliable hydroelectric power and towards alternative energy sources. The current increase in thermal electrical sources is a positive step forward (USAID n.d.), but the government should also fund solar and nuclear electrical generation projects.

1. In northern Ghana especially, there is interest at the district assembly level in building solar plants as the climate and terrain are very advantageous for harnessing the sun's power (Tamale District Assembly officials 2015).

2. Because Ghana is one of the few sub-Saharan African countries to have a functioning nuclear research reactor, they are also uniquely posed with existing domestic expertise and capabilities in both nuclear engineering and safety protocols that would make partially transitioning to nuclear power sources a viable solution. It is estimated that just one nuclear reactor could produce almost 50\% of Ghana's current energy consumption (Mantey 2014).

While the government has made numerous promises to commence work on building alternative energy generation sources including solar and nuclear plants, projects to date have been stalled, and there is a lack of funding commitment and political engagement.

\section{Conclusion}

In many ways, Ghana is considered a development success story in sub-Saharan Africa. They have passed Huntington's "two-turnover" test for democratic consolidation (Huntington 1991) and have consistently been at the top of rankings of African countries' development indicator. However, the current load shedding crisis threatens to disrupt these decades of development advancements. While have been some observable improvements in decreased load shedding since the power barges arrived in late 2015, if Ghana wants to permanently vanquish dumsor and achieve genuine electrical stability, politicians need to look beyond the next electoral cycle in order to implement long-term, sustainable solutions to the energy crisis. 


\section{References}

Aiddoo, Kobina. "The Dumsor Report." African Centre for Economic Transformation, 2015. Accessed February 1, 2016 http://citifmonline.com/2015/08/06/scientific-dumsor-report-see-whichareas-enjoy-or-suffer-most/

Ackah, Dr. Charles. "Electricity insecurity and its impact on micro and small businesses." Report presentation given to Economy of Ghana Network of the Institute of Statistical, Social, and Economic Research, May 14, 2015. http://isser.edu.gh/index.php/isser-latest-news/92workshop-on-electricity-insecurity-and-its-impact-on-the-economy-of-ghana

Antwi, Sampson. "State of Renal Replacement Services in Ghana." Blood Purification 39, no. 1-3 (2015): 137-140.

Anuomi, Dennis Sitsofe. Power Quality and Industrial Performance. Hamburg, Germany: Anchor Academic Publishing, 2015.

"Approved Tariff." Table published by Electricity Company of Ghana. October, 2014. Accessed February 1, 2016 http://www.ecgonline.info/index.php/customer-care/approved-tarrif

"Doing Business: Ghana." World Bank Group. Accessed February 1, 2016 at http://www.doingbusiness.org/data/exploreeconomies/ghana/getting-electricity/

"Dumsor-dumsor causing poor academic performances in Ghana - NUGS." NewsGhana. February 26, 2015. Accessed February 1, 2016 http://www.newsghana.com.gh/dumsor-dumsor-causingpoor-academic-performances-in-ghana-nugs/

Dunn, Lauren. "What Leads to a Mobile Banking Program's Success? A Comparison of M-Pesa and EKO India Financial Services." Journal of Public and International Affairs 26, (2015): 108-117.

"Ghana Electricity Crisis (dumsor) - The Causes, Disadvantages and Solutions." Ghanaian Chronicle. March 5, 2015. Accessed January 19, 2016 http://allafrica.com/stories/201503051476.html

"Ghana's load shedding end of 2015." NewsGhana. December 30, 2015. Accessed February 1, 2016 http://www.newsghana.com.gh/ghanas-load-shedding-end-for-2015/

Heeralall, Nirmal and Raoudha Ben Abdelkrim. "The world's fastest growing middle class." UHY International, 2012. http://www.uhy.com/the-worlds-fastest-growing-middle-class/

Huntington, Samuel. The Third Wave: Democratization in the Late Twentieth Century. University of Oklahoma, 1991.

Mantey, Joana. "Ghana prepares for nuclear energy program." Voice of America. December 18, 2014. Accessed online on February 1, 2016 at http://www.voanews.com/content/ghana-prepares-fornuclear-energy-program/2563919.html

Quartey, Kwei. "Travels to the 'Dark Country.'” Latest News (blog), 2016. Accessed January 19, 2016 http://www.kweiquartey.com/latest-news/travels-to-the-dark-country/

Rademacher-Schulz, Christina and Edward Salifu Mahama. "Where the Rain Falls - Case Study: Ghana." Report No. 3. Bonn, Germany: United Nations University Institute for Environment and Human Security, 2012. 
Tamale District Assembly officials. Presentation to Carleton University Students. Tamale, Northern Ghana, May 202015.

Wadie, Linda Abrefi. “Dumsor explained." GhanaWeb, 2015 Accessed January 19, 2016 http://www.ghanaweb.com/GhanaHomePage/NewsArchive/Dumsor-explained-357482

"What is load shedding?" Eskom South Africa. Accessed January 19, 2016 http://loadshedding.eskom.co.za/loadshedding/description

"What Power Africa Means for Ghana." USAID. Accessed online on February 1, 2016 at https://www.usaid.gov/powerafrica/partners/african-governments/ghana

World Development Index Databank. World Bank. Various data sets accessed online on January 19, 2016. 